\title{
COMBINING ABILITY AND TYPE OF GENE ACTION FOR GRAIN YIELD AND SOME OTHER TRAITS USING LINE $X$ TESTER ANALYSIS IN NEWLY YELLOW MAIZE INBRED LINES (Zea mays L.). \\ Aly, R. S. H. and E. A. Amer \\ Maize Research Program, FCRI, ARC, Egypt
}

\begin{abstract}
Fourteen newly yellow inbred lines of maize were topcrossed with the two inbred line testers; Giza-638 and Giza-649 at Sids Agricultural Research Station in 2005growing season. The 28 topcrosses in addition to two yellow single crosses; SC 155 and SC 3084 as check varieties were evaluated in 2006 season at two locations; Sakha and Sids Agric. Res. Stns. The studied traits were number of days from planting to date of $50 \%$ silking, plant height, ear height, infection of late wilt\% disease, number of ears/ 100 plants and grain yield in (ard/fed). Highly significant differences were found between the two locations for the studied traits, these finding indicated that the traits differed from one location to another. Significant and highly significant mean squares for crosses, lines and testers were observed for all studied traits. Mean squares of lines $x$ testers interaction were highly significant for silking date, no. of ears $/ 100$ plant and grain yield. Interactions between crosses, lines, testers and line $x$ testers with locations were not significant. The parental inbred lines that exhibited desirable general combining ability (GCA) effects were $L_{4}, L_{5}, L_{7}, L_{12}$, for plant height toward shorter plants and ear height toward lower ear placement. Line-4 had negative and significant GCA effects for $50 \%$ silking toward earliness, $L_{5}$ for grain yield, $L_{9}$ for no. of ears $/ 100$ plants, $L_{10}$ for no. of ears $/ 100$ plants and grain yield, $L_{14}$ toward earliness and grain yield and $L_{2}$ for grain yield. Generally, these inbred lines could be recommended for advanced stage of evaluation by maize program. Giza-638 $\left(T_{1}\right)$ tester was good general combiner for days to $50 \%$ silking toward earliness and ear height toward lower ear placement. While, Giza-649 $\left(T_{2}\right)$ tester was good general combiner for no. of ears $/ 100$ plants and grain yield. The highest SCA effects were observed in the topcrosses $L_{8} \times T_{2}, L_{13} \times T_{1}$ and $L_{14} \times T_{1}$ for grain yield, $L_{8} \times T_{2}$ and $L_{9}$ $x T_{2}$ for no. of ears $/ 100$ plants, $L_{7} \times T_{1}$ for infection of late wilt\% and $L_{12} \times T_{2}$ for earliness. Estimation of general combining ability variance components $\left(\sigma^{2} G C A\right)$ was larger than that of specific combining ability variance components $\left(\sigma^{2} S C A\right)$ for silking date, plant height and ear height, indicating that additive was found to be more important than non-additive gene action for these traits. While, the $\sigma^{2} \mathrm{SCA}$ was larger than $\sigma^{2} \mathrm{GCA}$ for infection of late wilt\%, no. of ears $/ 100$ plant and grain yield, indicating that the non-additive genetic variance played the major role than additive genetic variance in the inheritance of these traits. Topcrosses were significantly superior to the check SC 3084 (26.66 ard/fed) for grain yield, silking date (toward earliness), plant height (toward shorter plants) and ear height (toward lower ear placement). Generally, eight topcrosses; $\mathrm{L}_{8} \times \mathrm{T}_{2}$ (37.44 $\left.\mathrm{ard} / \mathrm{fed}\right), \mathrm{L}_{14} \times \mathrm{T}_{1}(37.40 \mathrm{ard} / \mathrm{fed}), \mathrm{L}_{2} \times \mathrm{T}_{2}(36.05$ ard/fed), $L_{10} \times T_{1}$ (35.96 ard/fed), $L_{9} \times T_{2}$ (35.32 ard/fed), $L_{5} \times T_{1}(35.24 \mathrm{ard} / \mathrm{fed}), L_{13} \times$ $\mathrm{T}_{1}$ (34.89 $\left.\mathrm{ard} / \mathrm{fed}\right)$ and $\mathrm{L}_{11} \times \mathrm{T}_{2}$ (34.76 ard/fed) were superior to the check SC 155 (34.08 ard/fed) for grain yield. Also, the three topcrosses; $L_{2} \times T_{1}$ (34.27 ard/fed), $L_{6} \times$ $\mathrm{T}_{1}(34.24 \mathrm{ard} / \mathrm{fed})$ and $\mathrm{L}_{10} \times \mathrm{T}_{2}(34.53 \mathrm{ard} / \mathrm{fed})$ were highly mean of grain yield, but they were not significant different from than the highly check SC 155.
\end{abstract}

Keywords: Maize, Zea mays L., Topcrosses, Line x tester, Combining ability, Gene action. 


\section{INTRODUCTION}

Successful development for improving high yielding maize hybrid and related traits such as earliness, shorter plants, lower ear placement and high resistance of late wilt disease caused by Cephalosprium maydis is based mainly on accurate evaluation of inbred lines under selection and that is a major aim in the national maize research program. In fact plant breeding uses selection from the available genetic variability for crop improvement (Asins, 2002). Topcrosses procedure was suggested by Davis (1927) to test the superior inbred lines for hybrid development programs. Jenkis (1978) stated that the topcross have been used fairly widely for the preliminary evaluation of combining ability of new inbred lines, but there no general agreement as to the best type and number of testers for this purpose. Rawlings and Thampson (1962), Ameha (1977), Liakat and Tepora (1986), Al-Naggar et al. (1997) and Mosa et al. (2004), indicated the importance of using maize homozygous inbred line testers in the evaluation process. Numerous researchers reported that the variance components of SCA for grain yield and other traits were larger than these due to GCA, indicating that the importance of non-additive gene action in the inheritance of these traits; Mostafa et al. (1995), El-Shenawy et al. (2003) and Aly (2004) for grain yield. On contrary, Amer (2002), Amer et al. (2003) and Aly and Mousa (2008), reported that the additive genetic variance played an important role in the inheritance of silking date, plant height and ear height. The magnitude of $\sigma^{2} S C A \times$ location interactions was higher than those $\sigma^{2} \mathrm{GCA} \times$ location interactions for plant height, no. of ears $/ 100$ plant and grain yield, indicating that the non-additive gene action was affected more by environmental conditions than additive types for these traits; Soliman et al. (2001), Amer et al. (2002), El-Morshidy et al. (2003) and Aly (2004) for plant height, no. of ears/100 plant and grain yield. On the other hand, (Aly, 2004 and Aly and Mousa, 2008) reported that $\sigma^{2} \mathrm{GCA} \times$ location interactions was higher than $\sigma^{2} \mathrm{SCA} \times$ location interactions for silking date.

Therefore, the present study was carried out to, 1- Estimate of the combining ability for some newly yellow inbred lines of maize. 2 . Determine the most important mode of gene action that control traits under study, i.e. silking date, plant height, ear height, infection of late wilt\%, no. of ears/100 plant and grain yield. 3. Define the superior topcrosses to be used for improving and developing superior hybrids yielding ability in maize breeding programs.

\section{MATERIALS AND METHODS}

Fourteen yellow maize inbred lines derived through selection from segregating generations of bank-354 (the origin of Puerto Rico Crupo5 \#218, Indian) were chosen for this study. These lines were topcrossed to two testers i.e., Giza-638 and Giza-649 at Sids Agricultural Research Station during 2005 growing season. In the growing season 2006, the 28 crosses and two checks; SC 155 and SC 3084 were evaluated at two locations; 
Sakha and Sids Agricultural Research Stations. Each experiment was arranged in a randomized complete blocks design with four replications. Plot size was one row, $6 \mathrm{~m}$. long and $80 \mathrm{~cm}$. apart. Seeds was planted in hills evenly spaced at $25 \mathrm{~cm}$. a long the row at the rate of three kernels per hill. Seedling was thinned to one plant per hill after 21 days from planting. All agronomic field practices were applied as recommended. Data were recorded number of days from planting to date of $50 \%$ silking emergence, plant height $(\mathrm{cm})$, ear height $(\mathrm{cm})$, infection of the late wilt disease $\%$, number of ears $/ 100$ plants and grain yield (ard/fed) adjusted to $15.5 \%$ moisture content (one ardab $=140 \mathrm{~kg}$ and one feddan $=4200 \mathrm{~m}^{2}$ ). Statistical analyses were performed for each location then combined over locations according to Steel and Torrie (1980). The combining ability analysis was estimated using the line $x$ tester procedure suggested by Kempthorne (1957). Combined analysis among the two locations was done on the based of homogeneity test.

\section{RESULTS AND DISCUSSION}

Analysis of variances for all the studied traits, i.e., number of days to $50 \%$ silking, plant height $(\mathrm{cm})$, ear height $(\mathrm{cm})$, infection of late wilt\%, no. of ears/100 plant and grain yield (ard/fed) combined over both locations are presented in Table 1.

Table 1. The results of the analysis of variances for all the studied traits over both locations.

\begin{tabular}{|c|c|c|c|c|c|c|c|}
\hline S.O.V. & D.F. & $\begin{array}{l}\text { Silking } \\
\text { date } \\
\text { (days) }\end{array}$ & $\begin{array}{l}\text { Plant } \\
\text { height } \\
\text { (cm) }\end{array}$ & $\begin{array}{c}\text { Ear } \\
\text { height } \\
\text { (cm) }\end{array}$ & $\begin{array}{c}\text { Infection } \\
\text { of } \\
\text { late wilt\% }\end{array}$ & $\begin{array}{c}\text { No. of } \\
\text { ears } / 100 \\
\text { plants } \\
\end{array}$ & $\begin{array}{c}\text { Grain } \\
\text { yield } \\
\text { (ard/fed) }\end{array}$ \\
\hline Locations (Loc.) & 1 & $198.754^{\star *}$ & $8489.469^{* *}$ & $3402.362^{* \star}$ & $128.532^{* *}$ & $264.698^{* *}$ & $768.165^{\star \star}$ \\
\hline Reps/Loc. & 6 & 5.957 & 515.79 & 417.975 & 6.71 & 31.302 & 48.91 \\
\hline Crosses ( C ) & 27 & $15.543^{* *}$ & $1675.977^{\star *}$ & $941.534^{\star *}$ & $12.22^{\star \star}$ & $780.11^{* *}$ & $47.959^{* *}$ \\
\hline Lines (L) & 13 & $28.046^{* *}$ & $3369.553^{* *}$ & $1789.74^{\star *}$ & $14.594^{* *}$ & $833.703^{* *}$ & $54.009^{* *}$ \\
\hline Testers (T) & 1 & $27.862^{\star *}$ & $367.719^{*}$ & $1425.112^{\star \star}$ & $27.904^{*}$ & $4140.9^{* *}$ & $132.586^{\star *}$ \\
\hline Lines $\times$ Testers & 13 & $2.092^{* *}$ & 83.036 & 56.131 & 8.64 & $467.994^{* *}$ & $43.092^{* *}$ \\
\hline $\mathrm{C} \times$ LOC. & 27 & 0.792 & 94.154 & 61.575 & $10.233^{\star *}$ & $198.149^{\star *}$ & $25.205^{\star *}$ \\
\hline Lines x Loc. & 13 & 0.62 & $156.075^{\star}$ & 74.842 & 9.096 & $274.884^{\star \star}$ & $33.841^{* \star}$ \\
\hline Testers x Loc. & 1 & 1.969 & 16.612 & 11.612 & $34.571^{*}$ & $580.18^{*}$ & 1.153 \\
\hline $\mathrm{L} \times \mathrm{T} \times \mathrm{LOC}$ & 13 & 0.873 & 38.198 & 52.15 & 9.498 & 92.026 & $18.426^{*}$ \\
\hline Pooled error & 162 & 0.861 & 84.343 & 57.715 & 5.478 & 98.302 & 9.48 \\
\hline
\end{tabular}

Results revealed that locations mean squares were highly significant for all the studied traits, indicating that environmental conditions were different at both locations since weather for these traits tend to be higher at Sids but more humid Sakha. These results are in agreement with those of El-Zeir et al. (2000), Mosa (2004) and Aly and Mousa (2008). Mean squares due to crosses $(C)$ and their partitions; line $(L)$, tester $(T)$ and $L \times T$ interactions were significant and highly significant for all the studied traits, except $L \times T$ for plant height, ear height and late wilt\%, which were not significant. These results indicated that both inbred lines and testers were significantly different from one each to another in topcrosses. Significant line $x$ tester interaction 
suggests that inbred lines may have different combining ability patterns and performed differently in crosses depending on type of tester used. Similar results were reported by El-Itriby et al. (1990), Amer et al. (2003), ElShenawy et al. (2003), Aly (2004), Parvez et al. (2007) and Aly and Mousa (2008). On the other hand, the interactions between (C x Loc) were highly significant for infection of late wilt\%, no. of ears/100 plants and grain yield. In addition, the line $x$ Loc interaction significant and highly significant for plant height, no. of ears $/ 100$ plants and grain yield. While, the Tester $x$ Loc interaction was significant for infection of late wilt\% and no. of ears $/ 100$ plants. Line $x$ Tester $x$ Loc interaction was not significant for all the studied traits, except for grain yield. Similar results were recorded by Mahmoud (1996), El-Shenawy et al. (2003) and Aly and Mousa (2008).

The calculated means and ranges for all studied traits over both locations are given in Table 2. The results showed that means and ranges of all studied traits for the two testers; Giza-638 and Giza-649 were not different. Generally, the results revealed that Giza-638 as a common tester, showed the desirable means for silking date (toward earliness), plant height (toward shorter plants), ear height (toward lower ear placement) and infection of late wilt\% (toward resistance to late wilt). On the other hand, the topcrosses that involved Giza-649 as a common tester showed the highest means for number of ears/100 plant and grain yield. These results are in harmony with those of Moentono (1989) and Mosa (2004) who stated that an efficient tester is the tester that is capable of showing greater ranges of variability of the performances of the topcross hybrids.

Table 2. The calculated means and ranges for all studied traits over both locations.

\begin{tabular}{|c|c|c|c|c|c|c|c|}
\hline Tester & Estimate & $\begin{array}{l}\text { Silking } \\
\text { date } \\
\text { (days) }\end{array}$ & $\begin{array}{l}\text { Plant } \\
\text { height } \\
(\mathrm{cm})\end{array}$ & $\begin{array}{c}\text { Ear } \\
\text { height } \\
\text { (cm) }\end{array}$ & $\begin{array}{c}\text { Infection } \\
\text { of } \\
\text { late wilt\% }\end{array}$ & $\begin{array}{c}\text { No. of } \\
\text { ears } / 100 \\
\text { plants }\end{array}$ & $\begin{array}{c}\text { Grain } \\
\text { yield } \\
\text { (ard/fed) }\end{array}$ \\
\hline \multirow{3}{*}{ Giza - 638} & Mean of Topcrosses & 64.05 & 240.16 & 129.07 & 0.690 & 101.43 & 32.61 \\
\hline & Range & 3.50 & 51.25 & 30.63 & 3.30 & 14.96 & 8.43 \\
\hline & Best Topcross & 62.38 & 222.00 & 115.75 & 0.00 & 108.81 & 37.40 \\
\hline \multirow{3}{*}{ Giza - 649} & Mean of Topcrosses & 64.76 & 242.72 & 134.12 & 1.36 & 110.00 & 33.41 \\
\hline & Range & 4.62 & 33.62 & 38.75 & 5.00 & 40.04 & 7.59 \\
\hline & Best Topcross & 62.38 & 223.13 & 117.50 & 0.00 & 140.04 & 37.44 \\
\hline
\end{tabular}

Mean performances of the topcrosses and the two checks for all the studied traits combined over the two locations are presented in Table 3 . The results showed that all topcrosses were significantly superior to the check SC $3084(26.66 \mathrm{ard} / \mathrm{fed})$ for grain yield, but eight topcrosses; $L_{2} \times \mathrm{T}_{2}$ (36.05 ard/fed), $L_{5} \times T_{1}$ (35.24), $L_{8} \times T_{2}$ (37.44 ard/fed), $L_{9} \times T_{2}$ (35.32 ard/fed), $L_{10} \times$ $\mathrm{T}_{1}(35.96 \mathrm{ard} / \mathrm{fed}), \mathrm{L}_{11} \times \mathrm{T}_{2}(34.76 \mathrm{ard} / \mathrm{fed}), \mathrm{L}_{13} \times \mathrm{T}_{1}(34.89 \mathrm{ard} / \mathrm{fed})$ and $\mathrm{L}_{14} \times$ $\mathrm{T}_{1}(37.40 \mathrm{ard} / \mathrm{fed})$ were significantly superior to the check SC 155 (34.08 ard/fed) for grain yield. Moreover, results revealed that the three topcrosses; $\mathrm{L}_{2} \times \mathrm{T}_{1}$ (34.27 $\left.\mathrm{ard} / \mathrm{fed}\right), \mathrm{L}_{6} \times \mathrm{T}_{1}$ (34.24 $\left.\mathrm{ard} / \mathrm{fed}\right)$ and $\mathrm{L}_{10} \times \mathrm{T}_{2}$ (34.53 $\left.\mathrm{ard} / \mathrm{fed}\right) \mathrm{had}$ higher means of grain yield, but they were not significantly different from the high yielding check SC 155. Results indicated that all topcrosses for silking date (toward earliness) and most of topcrosses for plant height (toward 
shorter plants) and ear height (toward lower ear placement) were significantly superior to the check SC 3084. Furthermore, four testcrosses; $L_{4} \times T_{1}, L_{12} \times$ $T_{2}, L_{13} \times T_{1}$ and $L_{14} \times T_{1}$ were earlier, had shorter plats and lower ear placement than the check SC 155. Also, most of the topcrosses appeared superior to the two checks for infection of the resistance to the late wilt disease.

Table 3: Mean performances of the topcrosses and the two checks for number of days to $50 \%$ silking, plant height $(\mathrm{cm})$, ear height (cm), infection of late wilt\%, no. of ears/100 plant and grain yield (ard/fed) combined over the two locations.

\begin{tabular}{|c|c|c|c|c|c|c|c|c|c|c|c|c|}
\hline \multirow[t]{2}{*}{ Lines } & \multicolumn{2}{|c|}{$\begin{array}{c}\text { Silking date } \\
\text { (days) }\end{array}$} & \multicolumn{2}{|c|}{$\begin{array}{l}\text { Plant height } \\
\text { (cm) }\end{array}$} & \multicolumn{2}{|c|}{$\begin{array}{l}\text { Ear height } \\
\quad \text { (cm) }\end{array}$} & \multicolumn{2}{|c|}{$\begin{array}{c}\text { Infection } \\
\text { of late } \\
\text { wilt } \%\end{array}$} & \multicolumn{2}{|c|}{$\begin{array}{c}\text { No. of } \\
\text { ears } / 100 \text { plants }\end{array}$} & \multicolumn{2}{|c|}{$\begin{array}{l}\text { Grain yield } \\
\text { (ard/fed) }\end{array}$} \\
\hline & $T_{1}$ & $\mathrm{~T}_{2}$ & $T_{1}$ & $T_{2}$ & $T_{1}$ & $T_{2}$ & $T_{1}$ & $\mathrm{~T}_{2}$ & $I_{1}$ & $T_{2}$ & $T_{1}$ & $T_{2}$ \\
\hline$e-1$ & 63.13 & 64.88 & 246.63 & 253.13 & 36.75 & 143.88 & 3.30 & 2.67 & 101.50 & 109.60 & \begin{tabular}{|l|}
28.97 \\
\end{tabular} & 31.25 \\
\hline line - 2 & 65.88 & 66.00 & 273.25 & 274.38 & 146.38 & 156.25 & 0.00 & 0.00 & \begin{tabular}{|l|}
99.06 \\
\end{tabular} & \begin{tabular}{|l|}
104.04 \\
\end{tabular} & \begin{tabular}{|l|}
34.27 \\
\end{tabular} & 36.05 \\
\hline line - - & 64.00 & 64.50 & 236.00 & 239.63 & 125.88 & 133.75 & \begin{tabular}{|l|}
0.00 \\
\end{tabular} & \begin{tabular}{|l|}
0.00 \\
\end{tabular} & 100.13 & \begin{tabular}{|l|}
105.60 \\
\end{tabular} & \begin{tabular}{|l|}
28.65 \\
\end{tabular} & \begin{tabular}{|l|}
31.67 \\
\end{tabular} \\
\hline line - 4 & 62.38 & 63.50 & 222.00 & 232.25 & 124.63 & 130.00 & \begin{tabular}{|l|}
0.54 \\
\end{tabular} & 0.00 & 96.80 & \begin{tabular}{|c|}
104.18 \\
\end{tabular} & \begin{tabular}{|l|}
30.47 \\
\end{tabular} & 32.70 \\
\hline line - 5 & 64.13 & 64.75 & 230. & 228 & 125.25 & & 0.00 & 0.00 & 31 & & 35.24 & 33.93 \\
\hline line - 6 & 65.25 & 67.00 & 247.25 & 24 & 136 & & 1.02 & 2.61 & & & 34.24 & 32.73 \\
\hline line - 7 & \begin{tabular}{|l|}
64.75 \\
\end{tabular} & 64.50 & 228.50 & 223 & 116.25 & & 0.00 & 5.00 & 102.75 & & 31.23 & 29.85 \\
\hline line - 8 & 65.13 & 65.88 & 250.38 & 255.38 & 137.88 & 142.38 & 1.00 & 1.59 & $\mid 102.09$ & \begin{tabular}{|l|}
140.04 \\
\end{tabular} & 30.25 & 37.44 \\
\hline line - 9 & 65.63 & 66.75 & 252.88 & 254.00 & 134.25 & 142.38 & 0.00 & 2.04 & 106.85 & 133.30 & \begin{tabular}{|l|}
32.77 \\
\end{tabular} & 35.32 \\
\hline line-10 & 65.00 & 65.63 & 255.25 & 256.75 & 139.50 & 143.38 & \begin{tabular}{|l|}
0.00 \\
\end{tabular} & 0.52 & 108.81 & 117.91 & 35.96 & 34.53 \\
\hline line-11 & 64.38 & 64.75 & 238.00 & 245.38 & 129.63 & 138.88 & \begin{tabular}{|l|}
0.54 \\
\end{tabular} & 0.50 & 98.08 & \begin{tabular}{|l|}
106.66 \\
\end{tabular} & 30.54 & 34.76 \\
\hline line-12 & 63.25 & 62.38 & 228.63 & & & & 1.09 & 2.50 & 93.85 & & 31.74 & 33.92 \\
\hline line-13 & 62.13 & 63.25 & 227.50 & 236 & 115.75 & 12 & 0.54 & 0.52 & 101.46 & & 34.89 & 31.28 \\
\hline line-14 & 61.75 & 62.88 & 225.63 & 227.75 & 118.50 & 118.88 & 1.64 & 1.04 & 104.35 & 104.51 & 37.40 & 32.31 \\
\hline SC-155 & \multicolumn{2}{|c|}{64.00} & \multicolumn{2}{|c|}{261.75} & \multicolumn{2}{|c|}{145.37} & \multicolumn{2}{|c|}{0.62} & \multicolumn{2}{|c|}{118.23} & \multicolumn{2}{|c|}{34.08} \\
\hline $\begin{array}{l}\text { SC- } \\
3084\end{array}$ & \multicolumn{2}{|c|}{68.00} & \multicolumn{2}{|c|}{265.50} & \multicolumn{2}{|c|}{148.37} & \multicolumn{2}{|c|}{0.00} & \multicolumn{2}{|c|}{98.78} & \multicolumn{2}{|c|}{26.66} \\
\hline $\begin{array}{l}\text { LSD } \\
0.05\end{array}$ & \multicolumn{2}{|c|}{0.172} & \multicolumn{2}{|c|}{1.701} & \multicolumn{2}{|c|}{1.407} & \multicolumn{2}{|c|}{0.433} & \multicolumn{2}{|c|}{1.836} & \multicolumn{2}{|c|}{0.570} \\
\hline 0.01 & \multicolumn{2}{|c|}{0.443} & \multicolumn{2}{|c|}{4.381} & \multicolumn{2}{|c|}{3.624} & \multicolumn{2}{|c|}{1.117} & \multicolumn{2}{|c|}{4.730} & \multicolumn{2}{|c|}{1.469} \\
\hline
\end{tabular}

$\mathrm{T}_{1}=$ tester-1=Giza-638

$\mathrm{T}_{2}=$ tester-2=Giza-649

General combining ability (GCA) effects for the parental inbred lines and the two testers for six traits combined over both locations are presented in Table 4. Results indicated that the inbred lines $L_{4}, L_{5}, L_{7}, L_{12}, L_{13}$ and $L_{14}$ exhibited desirable GCA effects for plant height toward shorter plants and ear height toward lower ear placement. On the other hand, line $L_{4}$ had negative and significant GCA effect for number of silking date toward earliness, line $L_{5}$ showed positive and significant GCA effect for grain yield, line $L_{9}$ had positive and significant GCA effect for no. of ears/100 plants, line $L_{10}$ had the highest positive and significant GCA effect for no. of ears/100 plants and grain yield, line $\mathrm{L}_{14}$ exhibited desirable GCA effect toward earliness and higher grain yield and line $L_{2}$ had highly positive and significant GCA effect for grain yield. Generally, these inbred lines could be recommended for advanced stage of evaluation through the breeding program. Results showed that the favorable GCA effects were recorded when $T_{1}$ was used for days to $50 \%$ silking toward 
earliness and ear height tower lower ear placement, while $T_{2}$ for no. of ears/100 plants and grain yield. These results are in agreement with those by Liakat and Tepora (1986), Soliman and Sadek (1999), El-Shenawy et al. (2003) and Aly and Mousa (2008). They found that the superior inbred lines should be used as testers to evaluate and select the best lines with highest GCA effects.

Table 4. General combining ability (GCA) effects for the fourteen inbred lines and the two testers for number of days to $50 \%$ silking, plant height $(\mathrm{cm})$, ear height $(\mathrm{cm})$, infection of late wilt\%, no. of ears/100 plant and grain yield (ard/fed) combined over both locations.

\begin{tabular}{|c|c|c|c|c|c|c|}
\hline & $\begin{array}{l}\text { Silking } \\
\text { date } \\
\text { (days) }\end{array}$ & $\begin{array}{c}\text { Plant height } \\
(\mathrm{cm})\end{array}$ & $\begin{array}{l}\text { Ear height } \\
\quad(\mathrm{cm})\end{array}$ & $\begin{array}{c}\text { Infection } \\
\text { of late wilt } \%\end{array}$ & $\begin{array}{c}\text { No. of ears/ } \\
100 \text { plants }\end{array}$ & $\begin{array}{l}\text { Grain yield } \\
\text { (ard/fed) }\end{array}$ \\
\hline Line -1 & -0.406 & $8.433^{* *}$ & $8.719^{* *}$ & $1.939^{* *}$ & -0.142 & $-3.139^{* *}$ \\
\hline Line-2 & $1.532^{\star \star}$ & $32.371^{\star \star}$ & $19.719^{\star \star}$ & -1.043 & -4.142 & $2.166^{\star \star}$ \\
\hline Line-3 & -0.156 & -3.629 & -1.781 & -1.043 & -2.829 & $-2.838^{\star *}$ \\
\hline Line-4 & $-1.469^{\star *}$ & $-14.317^{* *}$ & $-4.281^{*}$ & -0.510 & $-5.204^{*}$ & -1.411 \\
\hline Line-5 & 0.032 & $-12.005^{\star *}$ & $-6.156^{\star \star}$ & -1.043 & -1.723 & $1.588^{*}$ \\
\hline \begin{tabular}{|l|} 
Line-6 \\
\end{tabular} & $1.719^{* \star}$ & $4.808^{*}$ & $7.157^{* \star}$ & 0.772 & -3.585 & 0.506 \\
\hline Line-7 & 0.219 & $-15.630^{* *}$ & $-13.906^{\star *}$ & $1.458^{*}$ & -1.985 & $-2.457^{\star \star}$ \\
\hline Line-8 & $1.094^{\star \star}$ & $11.433^{\star *}$ & $8.532^{* \star}$ & 0.253 & $15.371^{\star *}$ & 0.849 \\
\hline Line-9 & $1.782^{\star \star}$ & $11.996^{\star \star}$ & $6.719^{\star \star}$ & -0.021 & $14.252^{\star \star}$ & 1.052 \\
\hline Line-10 & $0.907^{\star \star}$ & $14.558^{\star *}$ & $9.844^{\star *}$ & -0.782 & $7.671^{\star \star}$ & $2.246^{\star *}$ \\
\hline Line-11 & 0.157 & 0.246 & 2.657 & -0.521 & -3.323 & -0.350 \\
\hline Line-12 & -1.594 & $-13.817^{* *}$ & $-12.969^{* *}$ & 0.753 & $-8.767^{* \star}$ & -0.168 \\
\hline Line-13 & -1.719 & $-9.692^{\star *}$ & $-11.344^{* *}$ & -0.510 & -4.133 & 0.092 \\
\hline Line-14 & $-2.094^{\star *}$ & $-14.755^{\star \star}$ & $-12.906^{\star *}$ & 0.297 & -1.460 & $1.860^{\star}$ \\
\hline Tester-1 & $-0.353^{\star *}$ & -1.282 & $-2.523^{* *}$ & -0.353 & $-4.300^{* *}$ & $-0.582^{*}$ \\
\hline Tester-2 & $0.353^{\star \star}$ & 1.282 & $2.523^{\star \star}$ & 0.353 & $4.300^{* *}$ & $0.582^{*}$ \\
\hline LSD gi (L) 0.05 & 0.455 & 4.500 & 3.722 & 1.147 & 4.859 & 1.509 \\
\hline 0.01 & 0.598 & 5.914 & 4.892 & 1.507 & 6.386 & 1.983 \\
\hline \begin{tabular}{|lll} 
LSD gi $(T)$ & 0.05 \\
\end{tabular} & 0.172 & 1.701 & 1.407 & 0.443 & 1.836 & 0.570 \\
\hline 0.01 & 0.227 & 2.236 & 1.849 & 0.569 & 2.414 & 0.750 \\
\hline
\end{tabular}

Estimates of specific combining ability effects (SCA) for 28 topcrosses for silking date, plant height, ear height, infection of late wilt\%, no. of ears/100 plants and grain yield as a combined over all the two locations are shown in Table (5). The results showed that the best SCA effects were obtained in the topcrosses $L_{8} \times T_{2}, L_{13} \times T_{1}$ and $L_{14} \times T_{1}$ for grain yield, $L_{8} \times T_{2}$ and $L_{9} \times T_{2}$ for no. of ears $/ 100$ plants. While, the topcross $L_{7} \times T_{1}$ exhibited desirable SCA effects for infection of late wilt\%. Meanwhile, the topcross $L_{12} \times$ $\mathrm{T}_{2}$ possesses SCA effects for earliness trait.

Estimates of genetic variance components for all studied traits over the two locations and their interaction with locations are illustrated in Table 6. Results revealed that estimates of $\sigma^{2} \mathrm{GCA}$ for lines were higher in magnitude than those of $\sigma^{2} \mathrm{GCA}$ for testers for all the studied traits, except for grain yield indicating that most of the total GCA variances were due to the inbred lines and the contribution of lines were higher than the contribution of the testers 
for most of the traits. General combining ability variance components $\left(\sigma^{2} \mathrm{GCA}\right)$ was larger than that of $\sigma^{2} \mathrm{SCA}$ for silking date, plant height and ear height indicating that additive was more important than non-additive gene action for these traits. While, the $\sigma^{2}$ SCA was larger than $\sigma^{2} \mathrm{GCA}$ for infection of late wilt\%, no. of ears $/ 100$ plant and grain yield indicating that the nonadditive genetic variance played the major role than additive genetic variance in the inheritance of these traits.

Table 5. Specific combining ability effects for 28 topcrosses for silking date, plant height, ear height, infection of late wilt\%, no. of ears/100 plant and grain yield as a combined over all the two locations.

\begin{tabular}{|c|c|c|c|c|c|c|c|c|c|c|c|c|}
\hline & \multicolumn{2}{|c|}{$\begin{array}{c}\begin{array}{c}\text { Silking date } \\
\text { (days) }\end{array} \\
\end{array}$} & \multicolumn{2}{|c|}{$\begin{array}{c}\text { Plant height } \\
\text { (cm) }\end{array}$} & \multicolumn{2}{|c|}{$\begin{array}{l}\text { Ear height } \\
\text { (cm) }\end{array}$} & \multicolumn{2}{|c|}{$\begin{array}{c}\text { Infection of } \\
\text { late wilt\% }\end{array}$} & \multicolumn{2}{|c|}{$\begin{array}{l}\text { No. of ears/ } \\
100 \text { plants }\end{array}$} & \multicolumn{2}{|c|}{$\begin{array}{c}\text { Grain yield } \\
\text { (ard/fed) }\end{array}$} \\
\hline & $\mathrm{T}_{1}$ & $T_{2}$ & $\mathrm{~T}_{1}$ & $T_{2}$ & $T_{1}$ & $\mathrm{~T}_{2}$ & T1 & $\mathrm{T} 2$ & T1 & T2 & T1 & T2 \\
\hline line -1 & -0.518 & 0.518 & -1.969 & 1.969 & -1.040 & 1.040 & 0.668 & -0.668 & 0.205 & -0.205 & -0.511 & 0.511 \\
\hline line - 2 & 0.290 & -0.290 & 0.719 & -0.719 & -2.415 & 2.415 & 0.353 & -0.353 & 1.812 & -1.812 & -0.511 & 0.511 \\
\hline line -3 & 0.103 & -0.103 & -0.531 & 0.531 & -1.415 & 1.415 & 0.353 & -0.353 & 1.562 & -1.562 & -1.129 & 1.129 \\
\hline line - 4 & -0.210 & 0.210 & -3.844 & 3.844 & -0.165 & 0.165 & 0.342 & -0.342 & 0.612 & -0.612 & -0.738 & 0.738 \\
\hline line -5 & 0.040 & -0.040 & 0.719 & -0.719 & 2.335 & -2.335 & 0.353 & -0.353 & 5.143 & -5.143 & 1.035 & -1.035 \\
\hline line -6 & -0.523 & 0.523 & 2.282 & -2.282 & 0.397 & -0.397 & -0.442 & 0.442 & 1.718 & -1.718 & 1.116 & -1.116 \\
\hline line -7 & 0.478 & -0.478 & 3.969 & -3.969 & 1.085 & -1.085 & $-2.147^{\star \star}$ & $2.147^{\star \star}$ & 3.343 & -3.343 & 1.072 & -1.072 \\
\hline line -8 & -0.023 & 0.023 & -1.219 & 1.219 & 0.273 & -0.273 & 0.058 & -0.058 & $-14.676^{* \star}$ & $14.676^{* *}$ & $-3.215^{\star \star}$ & $3.215^{\star *}$ \\
\hline line - 9 & -0.210 & 0.210 & 0.719 & -0.719 & -1.540 & 1.540 & -0.669 & 0.669 & $-9.057^{*}$ & $9.057^{\star}$ & -0.894 & 0.894 \\
\hline line-10 & 0.040 & -0.040 & 0.532 & -0.532 & 0.585 & -0.585 & 0.093 & -0.093 & -0.251 & 0.251 & 1.095 & -1.095 \\
\hline line-11 & 0.165 & -0.165 & -2.406 & 2.406 & -2.103 & 2.103 & 0.375 & -0.375 & 0.006 & -0.006 & -1.729 & 1.729 \\
\hline line-12 & $0.790^{*}$ & -0.790 & 2.282 & -2.282 & 3.648 & -3.648 & -0.352 & 0.352 & 1.225 & -1.225 & -0.711 & 0.711 \\
\hline line-13 & -0.210 & 0.210 & -2.969 & 2.969 & -1.978 & 1.978 & 0.364 & -0.364 & 4.206 & -4.206 & $2.186^{*}$ & $-2.186^{\star}$ \\
\hline line-14 & -0.210 & 0.210 & 0.219 & -0.219 & 2.335 & -2.335 & 0.651 & -0.651 & 4.106 & -4.106 & $2.933^{\star \star}$ & $-2.933^{* *}$ \\
\hline $\begin{array}{l}\text { Lsd } \\
0.05\end{array}$ & \multicolumn{2}{|c|}{0.643} & \multicolumn{2}{|c|}{6.364} & \multicolumn{2}{|c|}{5.264} & \multicolumn{2}{|c|}{1.621} & \multicolumn{2}{|c|}{6.870} & \multicolumn{2}{|c|}{2.134} \\
\hline 0.01 & \multicolumn{2}{|c|}{0.845} & \multicolumn{2}{|c|}{8.364} & \multicolumn{2}{|c|}{6.919} & \multicolumn{2}{|c|}{2.130} & \multicolumn{2}{|c|}{9.029} & \multicolumn{2}{|c|}{2.805} \\
\hline
\end{tabular}

Table 6. Estimates of genetic variance components for all studied traits over the two locations and their interaction with locations.

\begin{tabular}{|c|c|c|c|c|c|c|}
\hline $\begin{array}{l}\text { Genetic } \\
\text { parameters }\end{array}$ & $\begin{array}{c}\text { Silking } \\
\text { date } \\
\text { (days) }\end{array}$ & $\begin{array}{l}\text { Plant } \\
\text { height } \\
\text { (cm) }\end{array}$ & $\begin{array}{c}\text { Ear } \\
\text { height } \\
(\mathbf{c m})\end{array}$ & $\begin{array}{c}\text { Infection } \\
\text { of } \\
\text { late wilt \% }\end{array}$ & $\begin{array}{c}\text { No. of } \\
\text { ears/ } \\
100 \text { plants }\end{array}$ & $\begin{array}{c}\text { Grain } \\
\text { yield } \\
\text { ard/fed }\end{array}$ \\
\hline$\sigma^{2} L=\sigma^{2} G C A$ (Lines) & 1.622 & 205.285 & 108.226 & 0.372 & 32.857 & 0.682 \\
\hline$\sigma^{2} T=\sigma^{2}$ GCA (Testers) & 0.230 & 2.524 & 12.205 & 0.172 & 32.794 & 0.094 \\
\hline$\sigma^{2} \mathrm{GCA}=\sigma^{2}$ GCA (aver.) & 0.404 & 27.869 & 24.208 & 0.197 & 31.552 & 0.003 \\
\hline$\sigma^{2} L x T=\sigma^{2} S C A$ (aver.) & 0.154 & 0.087 & 0.052 & 0.395 & 46.212 & 4.202 \\
\hline $\begin{array}{l}\sigma^{2} \mathrm{GCA} / \sigma^{2} \mathrm{SCA}=\sigma^{2} \mathrm{GCA} \text { aver } \\
/ \sigma^{2} \text { SCAaver. }\end{array}$ & 2.623 & 320.333 & 465.538 & 0.499 & 0.683 & 0.0007 \\
\hline$\sigma^{2} L \times$ LOC $=\sigma^{2} G C A(L) \times$ LOC & -0.0316 & 14.7346 & 2.8365 & -0.0503 & 22.8573 & 1.9269 \\
\hline$\sigma^{2} T \times$ LOC $=\sigma^{2}$ GCA (T) $\times$ LOC & 0.0195 & -0.3855 & -0.7239 & 0.4477 & 8.7170 & -0.3084 \\
\hline $\begin{array}{l}\sigma^{2} \text { GCA } x \text { Loc }=\sigma^{2} \text { GCA aver. } x \\
\text { Loc }\end{array}$ & 0.013 & 1.505 & $-0.279 @$ & 0.385 & 0.485 & $-0.029 @$ \\
\hline $\begin{array}{l}\sigma^{2} L \times T \times \text { Loc. }=\sigma^{2} S \text { CA } \\
\text { average } \times \text { Loc }\end{array}$ & 0.003 & 11.536 & -1.391@ & 1.005 & 1.569 & 2.237 \\
\hline Contribution of Lines & 86.879 & 96.802 & 91.524 & 57.502 & 51.456 & 54.222 \\
\hline f Tester & .639 & 0.813 & 5.606 & 8.457 & 19.660 & 2.517 \\
\hline Contribution of $L \times T$ & 6.480 & 2.493 & 2.870 & 34.043 & 28.884 & 3.328 \\
\hline
\end{tabular}

@ Variance estimate proceeded by negative sign is considered zero (Robinson et al., 1955).

(T) Denote testers, (L) inbred lines and (Loc) locations. 
While, the $\sigma^{2}$ SCA was larger than $\sigma^{2} \mathrm{GCA}$ for infection of late wilt\%, no. of ears/100 plant and grain yield indicating that the non-additive genetic variance played the major role than additive genetic variance in the inheritance of these traits. These results are in agreement with those by ElZeir et al. (1993) and Mostafa et al. (1995) for silking date, plant height and grain yield; Aly and Mousa (2008) for silking date, plant height and ear height; Aly (2004) for silking date and no. of ears/100 plant; Mosa (2004) for silking date and grain yield; El-Shenawy et al. (2003) for silking date, plant height, ear height and grain yield, and Tabassum et al. (2007) for grain yield. Moreover, results indicated that variance interactions of $\sigma^{2} G C A_{L} \times$ Location was higher than $\sigma^{2} G C A_{T} \times$ location for plant height, ear height, no. of ears $/ 100$ plant and grain yield, indicating that the $\sigma^{2} \mathrm{GCA}$ for lines was affected more by environment than by testers for these traits. Combined data revealed that the variance of $\sigma^{2} \mathrm{GCA} \times$ location interaction was either smaller or negligible than the variance of $\sigma^{2} S C A x$ location interaction for infection of late wilt\%, no. of ears $/ 100$ plant and grain yield. These results indicated that non-additive type of gene action was more affected by environmental conditions than additive effects. Soliman et al. (2001), El-Morshidy et al. (2003), Aly and Mousa (2008) found similar results.

All possible simple correlation coefficients among studied traits were calculated and the results are shown in Table 7. Silking date was negative and significantly correlated with the other traits; plant height, ear height, no. of ears/100 plant and grain yield. Negative correlation indicated that the silking date decreased, but the other traits tended to increase. On the other hand, positive and significant correlation coefficient appeared between ear height with no. of ears/100 plant and between no. of ears/100 plant with grain yield. Similar results were obtained by El-Zeir (2001), Amer et al. (2002), Mosa (2003), Saleem et al. (2007) and Shakoor et al. (2007).

Table 7: Simple correlation coefficient between grain yield and silking date, plant height, ear height and no. of ears/100 plant as a combined over all two locations.

\begin{tabular}{|l|c|c|c|c|c|}
\hline & $\begin{array}{c}\text { Silking } \\
\text { date }\end{array}$ & $\begin{array}{c}\text { Plant } \\
\text { height }\end{array}$ & Ear height & $\begin{array}{c}\text { No. of } \\
\text { ears/100 } \\
\text { plant }\end{array}$ & $\begin{array}{c}\text { Grain yield } \\
\text { (ard/fed) }\end{array}$ \\
\hline Silking date & - & $-0.734^{* *}$ & $-0.762^{* *}$ & $-0.493^{* *}$ & $-0.396^{*}$ \\
\hline Plant height & & -- & $0.935^{\star *}$ & $0.378^{*}$ & 0.312 \\
\hline Ear height & & & - & $0.418^{*}$ & 0.269 \\
\hline No. of ears/100 plant & & & & - & $0.492^{* *}$ \\
\hline Grain yield (ard/fed) & & & & & - \\
\hline
\end{tabular}

${ }^{*}{ }^{* \star}$ significant at 0.05 and 0.01 levels of probability, respectively. 


\section{REFERENCES}

Al-Naggar, A.M.; H.Y.El-Sherbieny and A.A. Mahmoud (1997). Effectiveness of inbreds, single crosses and populations as tester for combining ability in maize. Egypt. J. Plant Breed., 1: 35 - 46.

Aly, A.A. (2004). Combining ability and gene action of new inbred maize lines (Zea mays L.) using line $x$ tester analysis. Egypt. J. Appl. Sci., 19(12 B): $492-518$.

Aly, R.S.H. and S.Th.M. Mousa (2008). Estimation of combining ability for newly developed white inbred lines of maize (Zea mays L.) via line $x$ tester analysis. Egypt. J. of Appli. Sci., 23(2B): $554-564$.

Ameha, M. (1977). Comparison of S2 progeny and inbred tester methods for improving maize. Ph. D. Thesis, Fac. Agric., lowa State Univ., USA.

Amer, E.A. (2002). Combining ability on early maturing inbred lines of maize. Egypt. J. Appl. Sci., 17(5): $162-181$.

Amer, E.A.; A.A. El-Shenawy and A.A. Motawei (2003). Combining ability of new inbred lines via line $x$ tester analysis. Egypt. J. Plant Breed., 7(1): $229-239$.

Amer, E.A.; A.A. El-Shenawy and H.E. Mosa (2002). Evaluation of some new inbred lines of maize for combining ability. Annals of Agric. Sci., Moshtohar, 40(2): $2791-2190$.

Asins, M.J. (2002). Present and future QTL analysis in plant breeding. Plant Breed, 121: $281-286$.

Davis, R.L. (1927). Report of the plant breeding. Ann. Rep. Puerto Rico Agric. Res., 48: $14-45$.

El-Itriby, H.A.; M.M. Ragheb, H.Y. El-Sherbiney, M.A.K. Sherieny (1990). Estimates of combining ability of maize inbred lines in topcrosses and its interaction with environment. Egypt. J. Appl. Sci., 5(8): $354-370$.

El-Morshidy, M.A.; E.A. Hassaballa; Sh.F. Abou-Elsaad and M.A. Abd ElMoula (2003). Combining ability and type of gene action in maize under favorable and water stress environments. Egypt. J. Plant Breed., 7(1): $55-75$.

El-Shenawy, A.A.; E.A. Amer and H.E. Mosa (2003). Estimation of combining ability of newly developed inbred lines of maize by (line $x$ tester) analysis. J. Agric. Res. Tanta Univ., 29(1): $50-63$.

El-Zeir, F.A.; A.A. Abdel-Aziz and A.A. Galal (1993). Estimation of heterosis and combining ability effects in some new top crosses in maize. Minufiya J. Agric. Res. 4 (1): 2179 - 2190.

El-Zeir, F.A.; E.A. Amer and H.E. Mosa (2001). Combining ability for two sets of white and yellow diallel crosses for agronomy traits, resistance to disease, chlorophyll and grain yield of maize. J. Agric. Sci., Mansoura Univ., 26(2): $703-714$.

El-Zeir, F.A.; E.A. Amer; A.A. Abdel-Aziz and A.A. Mahmoud (2000). Combining ability of new maize inbred lines and type of gene action using top crosses of maize. Egypt. J. Appl. Sci., 15(2): 116 - 128. 
Jenkins, M.T. (1978). Maize breeding during the development and early years of hybrid maize. In Walden, D.B. (ed.) Maize breeding and genetics. New York, Wiley. Interscience Pupl.

Kempthorne, O. (1957). An introduction to genetic statistical. John WileySons Inc., New York U.S.A.

Liakat, M.A. and N.M. Tepora (1986). Comparative performances of four types of testers for evaluating corn lines from two populations. Philippine. J. Crop Sci., 4(5): 175 - 179

Mahmoud, A.A. (1996). Evaluation of combining ability of newly developed inbred lines of maize. Ph.D. Thesis, Fac. Agric. Cairo Univ., Egypt.

Moentono, M.D. (1989). Efficient tester for evaluation of combining ability of downy mildew resistant inbred lines in the development of hybrid corn. Indonesian J. Crop Sci., 4(1): 41 - 51 .

Mosa, H.E. (2003). Heterosis and combining ability in maize (Zea mays L.). Minufiya J. Agric. Res. 28 (1): 1375 - 1386.

Mosa, H.E. (2004). Comparison between two types of testers for evaluating new white inbred lines of maize. Annals of Agric. Sci., Moshtohor, 42(2): $475-487$.

Mosa, H.E.; A.A. Motawei and Afaf, A.I. Gabr (2004). Evaluation of new inbred lines of yellow maize via line $x$ tester analysis over three locations. J. Agric. Sci., Mansoura Univ., 29(3): 1023 - 1033.

Mostafa, M.A.; F. A. Salama and A.A. Abdel-Aziz (1995). Combining ability of white maize population with inbred testers. J. Agric. Sci., Mansoura Univ., 20(1): 143 - 149.

Parvez A. Sofi; A.G. rather and Zahoor Dar (2007). Association of heterotic expression for grain yield and its components traits in maize (Zea mays L.). International J. of Agric. Res., 2(5): 500 - 503.

Rawlings, J.O. and D.L. Thompson (1962). Performance level as criterion for the choice of maize testers. Crop Sci., 2: $217-220$.

Robinson, J.O.; R.E. Comstock and P.H. Harvey (1955). Genetic variance in open pollinated varieties of corn. Genetics, 40: $45-60$.

Saleem, A.; U. Saleem and G.M. Subhani (2007). Correlation and path coefficient analysis in maize (Zea mays L.). Journal of Agric. Res. (Pakistan), 45(3): $177-183$.

Shakoor, M.S.; M. Akber and A. Hussain (2007). Correlation and path coefficient studies of some morphological traits in maize double crosses. Pakistan J. of Agric. Sci., 44(2): $213-216$.

Soliman, F.H. and S.E. Sadek (1999). Combining ability of new maize inbred lines and its utilization in the Egyptian hybrid program. Bull. Fac. Agric. Cairo Univ., 50: 1 - 20.

Soliman, F.H.S.; S.H.A. Shafay; A.I. El-Agamy and M.A. Mostafa (2001). Combining ability in maize topcrosses for grain yield and oil content. Egypt; J. Plant Breed. 5: $43-60$.

Steel, R.G. and J.H. Torrie (1980). Principal and procedures of statistics. Mc Grow Hill Inc., New York U.S.A.

Tabassum, M.I.; M. Saleem, M. Akbar, G.Y. Ashraf and N. Mahmood (2007). Combining ability studies in maize under normal and water stress conditions. Journal of Agric. Res. (Pakistan), 45(4): 261 - 268. 


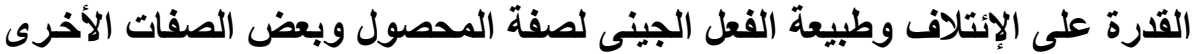

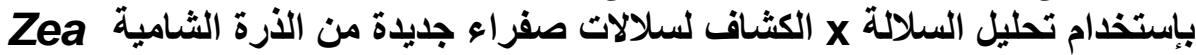

(mays L.)

رزق صلاح حسانين على و عصام عبد الفتاح عامر مركز البحوث الزراعية ـ معهل بحوث عصد المحاصيل الحقلية ــ برنامج بحوث الذرة الثامية

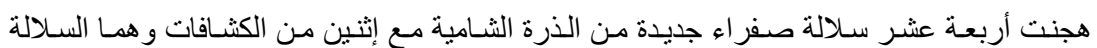

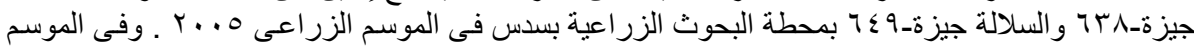

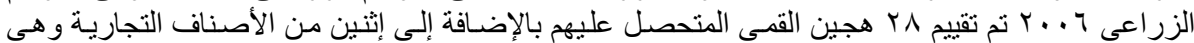

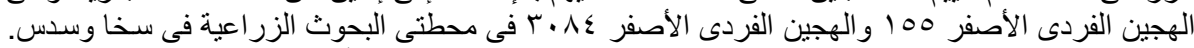

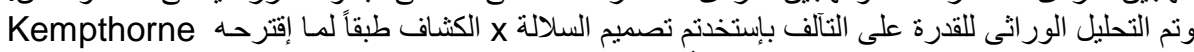

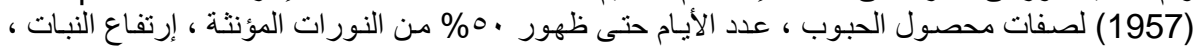

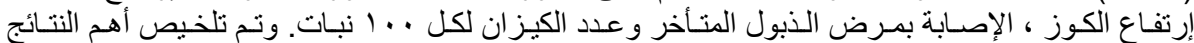

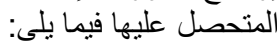

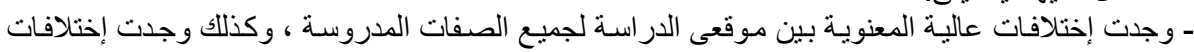

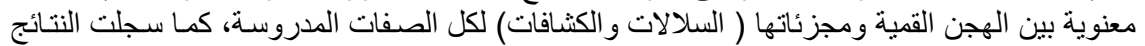

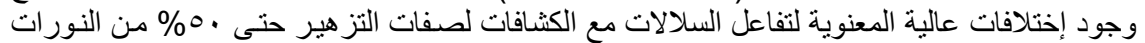

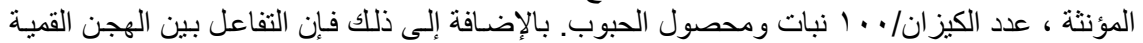

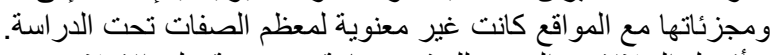

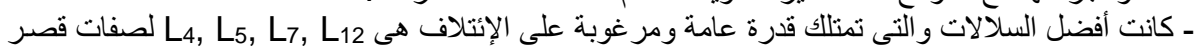

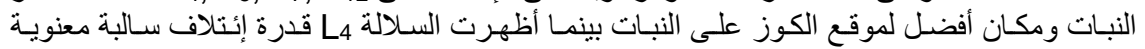

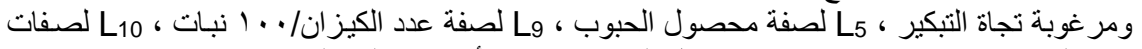

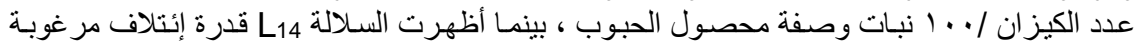

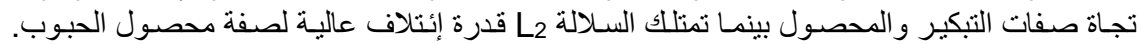

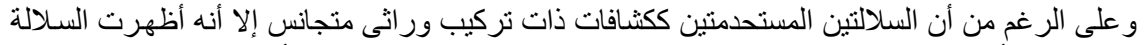

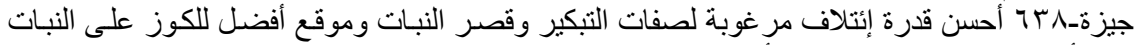

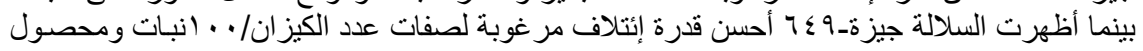

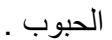

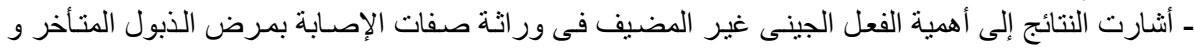

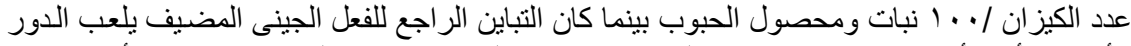

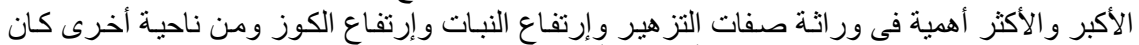

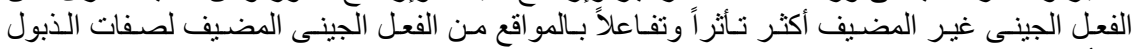

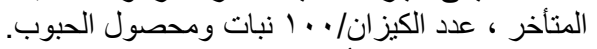

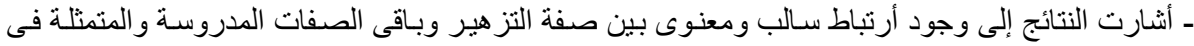

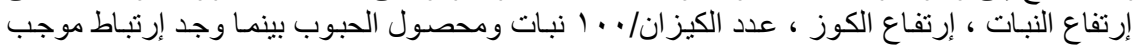

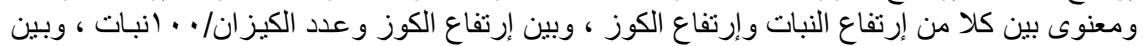

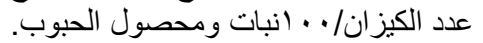

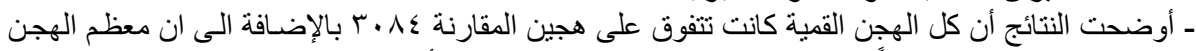

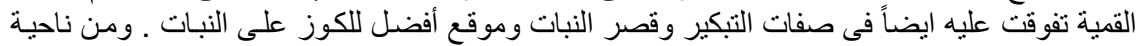

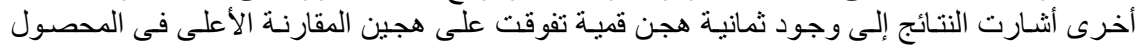

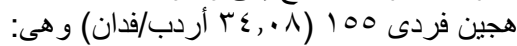

$\mathrm{L}_{8} \times \mathrm{T}_{2}$ (37.44 ard/fed), $\mathrm{L}_{14} \times \mathrm{T}_{1}$ (37.40 ard/fed), L2 X T2 (36.05 $\operatorname{ard} /$ fed), $L_{10} X T_{1}(35.96 \mathrm{ard} / \mathrm{fed}), \mathrm{L}_{9} X \mathrm{~T}_{2}$ (35.32 $\left.\mathrm{ard} / \mathrm{fed}\right), \mathrm{L}_{5} \times \mathrm{T}_{1}$ (35.24 ard/fed), $L_{13} \times T_{1}(34.89 \mathrm{ard} / \mathrm{fed})$ and $L_{11} \times T_{2}(34.76 \mathrm{ard} / \mathrm{fed})$. 